\title{
DATING AND DEBATING: LATE PATRIARCHS AND EARLY CANON ${ }^{1}$
}

\author{
Christo Lombaard \\ Christian Spirituality \\ University of South Africa
}

\begin{abstract}
Building forth on a series of earlier contributions in which the 'patriarchal era' is dated much later than has been commonly done, in this article the implications such a dating has for the early phase of canon formation are considered. The patriarchs are namely not considered to be either early, pre-monarchical figures about whom traditions were kept alive for centuries in ancient Israel until written down, nor are they considered to be purely literary figments of folk imagination, as had been the dominant two trends in critical scholarship. Moreover, none of the patriarchal figures are understood to be singular figures; rather, they are composite figures as we encounter them in the Pentateuch, created by means of the conflation of 'historical' narratives about different tribal leadership figures, presented in the mode of legend (either as a natural conflation of legendary material, or as a means of unifying more closely some loosely-related groups). This means that the canon, as it was being formed in the post-exilic period, reflected the 'internal' tensions between the various tradent groups of the patriarchal figures as they jostled for power with one another, but reflected also the 'external' tensions, as the patriarchal groups together are in discussion with other social and theological streams in that society. In order to establish more firmly the role of the patriarchal tradent groups in society, the 'patriarchal era' was not presented as having been a relatively recent period, but was imagined in an ancient past, and as such found placement within the canon-in-development, in order to establish their legitimacy on the basis of antiquity.
\end{abstract}

Key Words: Patriarchal Era; Patriarchal Narratives; Tradent Groups; Patriarchal Groups; Late Dating; Early Canon

\section{Predating and Debating}

This article consists of two main parts. In the first part, the author's developing theory on understanding the patriarchs of ancient Israel is summarised; in the second part, how this relates to early post-exilic canon formation is taken into consideration. The latter namely constitutes the new contribution this article has to offer.

The first main part of the article considers the dating of the patriarchal figures in relation to the Old Testament texts on them. Initially, the point is made that Old Testament scholarship somewhat strangely still holds onto a basic chronological framework provided

This article was presented as a paper at the $21^{\text {st }}$ Congress of IOSOT (the International Organisation for the Study of the Old Testament), Munich, 4-9 August 2013. 
within the Old Testament texts. However, from the vantage point of the extra-Pentateuchal references to the patriarchs, it becomes possible to envision that framework differently. With such a dating of the respective patriarchs, a different possibility to the present alternatives is opened on the relationship between patriarchal figures and patriarchal texts.

This different possibility is considered in the second main part of the article, namely as it is directly related to the intensely contestational period within post-exilic Judea. Therefore, different socio-literary streams within this period are indicated; naturally, simplified. Next, the point is made that it is within this context that the patriarchal accounts are rearranged, reflecting the emerging social realities among the patriarchal tradents. Apart from a resultant reordering of the patriarch accounts, for the sake of attaining social legitimacy, these accounts are also aggrandised in size and age. In closing, it is argued that such machinations reflect the diversity within post-exilic Judah; yet the fact that they indeed found reflection in a shared yet varied canon, as it was coming into being, helped sociologically to create and maintain a sense of social cohesion among the respective groups.

\section{Dating: The Patriarchs in Text, History and Historiography}

Despite the strongly critical views for centuries now on the body of Pentateuchal texts that refer to the patriarchs of ancient Israel, the idea that there was a pre-monarchical 'patriarchal era' is held fairly widely. The exception to this is the relatively small group of scholars who regard the whole idea of the patriarchs to be fictional narratives within Judea (e.g. Davies 2006:28; cf. Howard 2003:45-47 for a brief summary). Apart from this group, though, the standard view of the flow of the historical periods surrounding the patriarchal era continues to look something like this:

- Prehistory

- Patriarchal era

- Exodus

- et cetera

'History' thus begins with the patriarchs (Genesis 11:26). This follows precisely the Old Testament's own telling of the history of ancient Israel (cf. e.g. Miller \& Hayes 1986:86), despite the early realisation already that the texts of the Old Testament tell us more about their time of writing than about the times they write about (Wahl 1997:306-307, 310-311 summarises the views of De Wette, Wellhausen and Gunkel in this regard).

This leaves us with the interminably vexing question of when which text had been written, in order to deduce from each text the history of its own time.

There is within this broadly accepted schema some divergence on the dating accorded the patriarchal era. On the extreme side are authors (such as Berndt and Rathman 2003:37100) who attribute the patriarchs to the $20^{\text {th }}$ century BCE and earlier. Putting them aside, though, the dating of the patriarchal figures fluctuates generally between 1800 and 1200 BCE, with the Pentateuchal texts referring to them dated to between 950 and 750 BCE.

It has become difficult to refer to these two broad possibilities as respectively conservative and liberal, because, as I pointed out in an earlier aside (Lombaard 2011a:473), these two groups at times come very close to one another with respect to the time span left between the patriarchal era and the texts on the patriarchs, at 250 years. In addition, when taken at their respective extremes, namely on the one hand with the era set at $1800 \mathrm{BCE}$ and the texts at $950 \mathrm{BCE}$, that leaves eight to nine centuries as a (very widely theorised) 
period of oral transmission; on the other hand, with the era set at $1200 \mathrm{BCE}$ and the texts at $750 \mathrm{BCE}$, that leaves four to five centuries as the oral transmission period - which itself implies no mean feat on the part of the theorised carriers of these traditions. As it turns out, these two broad possibilities do not differ much on the credulity required on the part of modern readers to sustain intellectually the duration of the interlude between patriarchal era and patriarchal text. Rather, the difference lies more on the matter of placement on the time line.

Moreover, the essential similarity of these two broad possibilities, and their related variants, remains this: that they follow as the basic time frame still that which the Old Testament's own historical framework of events presents. This is constituted by a patriarchal era before an Egypt - Exodus - Moses era, on its part placed before an era of judges, on which then follows statehood. However, the questioning of this own historical framework of the Old Testament has in fact long been taking place, in various ways (e.g. by the long-established realisation that the early prophetic literature largely predates the Pentateuch, and in recent decades by the so-called minimalists). So, to ask it again: ought this basic time outline of the Old Testament itself to be accepted still as 'working model' for our historical analyses? ${ }^{2}$

Linking this briefly for the moment to the theme of the process of canonisation, preparing the way for point 2 below, the question can be formulated differently: has this basic time outline of the Old Testament itself not been ideologically contrived, invented to respond to similar strategies by contemporary rival parties, thus creating ${ }^{3}$ a history? If so, though it is not unexpected that this imagined flow of history has since then been followed uncritically by those who hold these texts dear for reasons of identity and/or religion, why is this schema often adhered to also by us who study these texts for the additional/alternative reason of historical interest?

Perhaps as Pentateuch scholars we have been looking too committedly as 'insiders' to our body of texts, not venturing often enough outside the Pentateuch more narrowly and the historical literature in the Old Testament more broadly (cf. Lombaard 2013b, Lombaard 2010:1-5). What hardly ever comes into play, given this 'working model' as accepted historical framework, is for instance the role of the extra-Pentateuchal references in the Old Testament to the patriarchs (cf. Lombaard 2009:88-145). In the quest for a more complete historical reconstruction, or - to use the currently popular and intellectually more honest language from the humanities (cf. e.g. Gershoni 1992:5-37) - for a more nuanced reimagination of ancient Israel's past, should the possibilities of 'triangulation' (Lombaard

\footnotetext{
This is not meant as a question on the literary history of ancient Israel. That is but the first step. The question is on the relationship between, or more dynamically: the interaction between the 'events' within what is usually called Israel and the literature that tells of such events.

3 The recuperation by Gärtner 2012:11-15 of the distinction by Voegelin 1956/57 between pragmatic and paradigmatic historiography is useful in this regard. The latter employs the sense of the past of the former in order to make a point in the present, so that the past becomes a pliable tool for a contemporary purpose. Gärtner 2012:15 links this to the more familiar theological language of history and memory as employed by the Assmans (1994:111-140).

The idea of 'creating' a history may carry the connotation of falsity: that a past is fabricated, and that 'only' fiction is created (the kind of argument easy to fall into by minimalists). However, as philosophy of history has taught us, and as novelists frequently acknowledge, there is no firm separation between historiography and storytelling. The one cannot do without the other; the borderline between the two remains unclear; to keep to our topic here: all history is told. There is no other way. Moreover, the pastness of the past is such that it simply is inaccessible without theory (Le Roux 2001:444-457; more generally: Le Roux 1993:35-63), that is, without (informed) imagination.
} 
2013a:276-288) ${ }^{4}$ as they are offered by these references to the patriarchs that occur outside the Pentateuch not be considered more seriously?

Most obvious here would be Psalm 105 (cf. most recently Gärtner 2012:160-163), where Abraham, Isaac and Jacob are mentioned together. This reference does not help us much as an extra-Pentateuchal historical point of orientation on the patriarchs, though (cf. Lombaard 2011b:139-151, Lombaard 1998:59-70), given amongst other reasons the poetic nature of the Psalms. However the three prime references to the patriarchs among the prophets (here below now summarising Lombaard 2013a:276-288, 2013b, 2011a:470-486, 2010:1-5, 2008:907-919, 2005:152-159), are more fruitful since they indicate an awareness of the substance of the patriarchal stories as we know them from Genesis. These references, following for the moment the usually attributed dating, are Jacob/Israel/Ephraim in Hosea 12 , with the text traditionally dated to just before the last quarter of the $8^{\text {th }}$ century BCE, Isaac in Amos 7:9 \& 16, with the Isaac-insertions dated to the $7^{\text {th }}$ century BCE, and Abraham in Isaiah 29:22, with the reference dated post-exilicly. These three times that the individual patriarchs are mentioned outside of the Pentateuch thus provide points of orientation to which the dating of the Pentateuchal patriarchal references may in some way be tied.

The surprising matter, noticed for some time already, is that Abraham comes onto this extra-Pentateuchal scene so very late. As the most prominent of the patriarchs (themselves a group counting among the principal parts of Israel's faith history), also with whom the history proper of Israel begins in Genesis 12:1, one would expect more of him outside the Pentateuch, and earlier. Following on the ever later dating of the Pentateuchal compositional layers, combined with the redaction-historical work on the Isaiah text, it had, however, become easier to accept that the Abraham accounts had only really begun to play a role in Israel from the exile onwards. The Isaiah-Abraham references provided a secure enough tenter on which to hook these accounts, now accepted as late.

This left Jacob as primus inter patres - a comfortable consensus being maintained on Hosea 12, and a comforting one too, given that in this text so remarkably much of the (there summarised) Jacob narrative is clearly assumed to be fully familiar to the intended readership. However, most recently, the accepted dating of roughly 730-725 BCE has been questioned foundationally, first of chapter 12 itself (cf. Römer 2011, drawing on e.g. Nissinen 1991), and now for the book as a whole (Bos 2013, but with only a small section on Hosea 12). Though containing traditions from earlier, it now seems that the book of Hosea essentially came into being in the Persian period, reacting directly against dynamics in Yehud during that time - a convincing argument, relying methodologically, not unlike my own developing understanding of the patriarchs, on what the texts may well be referring to most directly. Ever more clearly, then, chapter 12 with its assumption of a highly developed broader knowledge of the Jacob accounts fits better with this later period.

This leaves us with the unforeseen situation that the most diminutive of the patriarchs from Genesis, and the southern-most, from Beersheba, may indeed be the first. The patriarchs' history in Israel would then start, most probably, in $7^{\text {th }}$ century Judea, with Isaac.

This term is here meant in its observational sense, and not methodologically. A new perspective is offered by taking a different vantage point. The basic methodological approach of historical reconstruction (or reimagination), tentative as it always is because it is wrought with the difficulties of deducing insights from texts not intended to tell us what we ask of them, remains in place. 
This development would date the personage of this patriarch (be it actual or legendary, but in either case, iconic) roughly half a millennium after the latest time frame of $1200 \mathrm{BCE}$ usually ascribed to the patriarchal era. A central aspect of this developing understanding of the patriarchs is that they did not 'exist' (again: be it actual or legendary - that question is not essential at present to the development of this understanding) centuries before the texts that refer to them. They were, rather, roughly contemporary figures to the texts related to them.

This working hypothesis is based on a methodologically more satisfying alternative to the two main trends in modern scholarship on the patriarchal traditions:

- The first is the postulate of a centuries long period of unbroken oral transmission of patriarchal traditions from generation to generation among a small group of tradents - with all the uncertainties that this has entailed for Old Testament scholarship;

- The second is the newer postulate, reacting directly on the first, that the patriarchal narratives are fully fictional, so that no patriarchal figures should be accepted as ever having existed in ancient Israel, and with the whole of the body of literature around them regarded as contrived identity politicking during the Persian or Hellenistic eras - an understanding that is intellectually hardly more palatable that the one against which it reacts.

It is my contention that neither of these theories is completely wrong; they are simply overstating their respective cases. Namely:

- A period of oral transmission of accounts on an iconic patriarchal figure is fully likely. However, that theorised period need not last more than a few decades, at most.

- In addition, after developing methodological criteria to do so, each of the patriarchal accounts shall have to be weighed on the (non-absolute) balancing scales of probability as to their actual or fictive load, and along with that - see the second paragraph following - the extent of conflation of such contents to which they have been subjected.

In this proposed understanding, therefore, nothing is simplified: both up to now competing approaches remain in place, although changed. Everything is more complex. The historical situation of a patriarchal icon in its relation to each pertinent text will, from this proposed theoretical framework, have to be scrutinised anew.

Moreover, to add to the complexity, it seems that none of the patriarchal figures (yet again: be they actual or legendary) are singular figures. Each of them namely has a 'multiplex' character, in the sense that they are composite figures. This is reflected not only by the contradictions in the accounts that relate to them, but even in the multiple names associated with each of the patriarchs.

These are merely the outlines of my still-developing proposal.

Avant-garde as this understanding seems, it is proposed tremulously: not only because of its novelty, but also because all historical problems on the patriarchs have not been solved. However, some are; the creative impetus at least leads one to consider the remaining problems from a different perspective; in addition, some promising new interpretations become possible.

One of these relates to the context within which these accounts on the patriarchs found their way into the canon, through the early phases of its post-exilic development. 


\section{Debating: The Sociological Role of the Patriarchal Accounts within Post-exilic Judea}

Within a shifting broader context of post-exilic Judea in which the Persian influence, meant in several ways, induced from outside Judea, a growing economy and changed culture (cf. e.g. Fantalkin \& Tal 2012a:1-18, Fantalkin \& Tal 2012b:201-212), the internal dynamics of the people of 'Israel' was itself characterised by variety. These decades of return and restoration were for this re-emerging group perhaps its most intense internally diverse period of that millennium. The internal tensions were not limited to the well-known conflict between the returnees from exile and the am ha-aretz (cf. e.g. Usue 2005:189-146), with their particular claims to property and heritage. The internal streams of theological, historical and sociopolitical identity formations, all interwoven, included at least the following: start here

1. the school wisdom of the higher classes (probably returnees) and the folk wisdom of the lower classes, on one level, and on the philosophical front, the incompatible positions of the deterministic versus the non-deterministic views on the noncausality of suffering (most fully articulated in its diversity in the book of Job);

2. the priestly emphases on creation, law and (deuteronomistic) history (with, though certainly later and perhaps not as deliberately as is the case in point 3 below, but then at least as a psychological reaction to the dour priestly legalism, the bodily hedonism of Song of Songs and the nihilistic hedonism of Qohelet);

3. the prophetic 'schools', varying in which historical prophets they represented (e.g. Amos or Isaiah, but with different ways of continuance of their ideas) and more strongly in the interests they promoted (e.g. Ezra-Nehemiah with an exclusivist stance vis-à-vis foreigners, for the sake of holiness, versus Jonah and Ruth with an inclusivist stance on this matter);

4. the temple staff such as the Levites who under the influence of the priests, custodians of the Torah, assembled, edited into five parts, and liturgically employed the Psalms;

5. the tradents of the patriarchal accounts on - in historical order - Isaac, Jacob and Abraham, who as a whole in a sense stood apart from the other streams just mentioned, yet internally a group with its own power struggles too (demonstrated by how the tradents of the individual patriarchs' traditions took over each other's accounts, with Genesis 12, $20 \& 26$ as the classic example of such machinations between the Abram/Abraham group/s and the Isaacites, and with Jeremiah 26:33 demonstrating a similar outcome for Isaac but with the emphasis now on Jacob - cf. Lombaard 2009:139-141)...

- $\quad .$. as did all the aforementioned streams;

- and only 'in a sense' do they all stand apart, since the influence of these forms of literature, and hence of the socio-theological 'streams' on one another has always been clear, though at different times in the research history this was characterised as affirming quotations (traditionally), adaptive reinterpretations (most famously, Von Rad 1962), and recently, subversive appropriations (e.g. Otto 2007:179-180);

- all of which streams, while engaged in rivalry for some kind of power on the public stages of society, demonstrate contestation 'internally', each within itself - leading at times to more or less natural assimilation of differences (as in the case with the diverse wisdom sayings within Proverbs), at times ending with intense threat of conflict (as in the case of Genesis 22, understood as a late text in 
which the Abraham group finally subjugates the Isaac group - cf. Lombaard 2008:907-919, and more popularly, Lombaard 2013c:34-36).

Clearly, diversity and contestation on all fronts were the characteristics of late $6^{\text {th }}$ and $5^{\text {th }}$ century Judaism. Therefore, in order to keep all these centrifugal social forces together in some way, the process of canonisation was the consequence. Precisely where the initiative lay remains unclear, as do the details of the process. It is, however, becoming increasingly clear that to typify the resultant canon as either an arena of contestation or as a compromise document, is to oversimplify matters. The canon was both. The diversity of theological streams found coherence not in complete social agreement, in which all but the dominant perspective is suppressed (although some were: for instance, the priests win overall - law and deuteronomistic theology becomes historically the most influential of the social streams; as an opposite example: among the patriarchs, Isaac becomes the minor figure), but the coherence is found in theological accord. The broadly understood shared reference to / reverence of Yahweh made for a theological consistency that was strong enough to create a sense of kinship, yet allowed at least some of the diffuse positions to remain intact, and to remain visible in the shared canon.

In fact, it may well be precisely this act of awkward coherence, of persistent diversity that ensured sociologically and philosophically the success of the process of canon formation (cf. Lombaard 2011c:49-65) and the endurance of the identities formed in relation to that canon-in-development.

The placement of the patriarchs in both the grands métarécits (to reinterpret the phrase from Lyotard 1979) of the opening books of the Old Testament, namely prehistory; patriarchal era; exodus; et cetera, and, summarised, in Psalm 105, surprisingly without creation or Zion theology but merged with Egypt; Exodus; Moses; Canaan, reflect related outcomes of this involved canonisation process.

Part of this canonisation process, sociologically understood, was that historicaltheological ideas held to be important, were aggrandised, namely by inflating both the scope and the antiquity of the favoured events and figures. Thus, for instance, kingship and David and the realm of Israel-Judah become in the post-exilic imagination an expanded and dated empire. Similarly, as a second example, the exodus becomes an epic of miracles and exponentially increased numbers, set even further back, before the advent of the state. In this logic of ancient Near Eastern historiography, everything becomes bigger and earlier as it is regarded as of greater importance. The tradents of the patriarchal stories follow suit.

Starting after the return from exile, narrativised (eventually now in this order) Abraham, Isaac and Jacob were in time historically imagined as having lived before the exodus. Even the more so: so long ago (read: so important) were these figures that they found canonical placement at the very beginnings of history. The only matters that precede them have to do with mythical pre-existence.

The patriarchs' stories frequently turn on divine promises as guarantees of the land - an existential issue after the exile. This assurance links well with the exodus account (which always implies the return from exile), but is a difficult fit with the conditional deuteronomistic theological stream that would come to rule the developing canonical and sociological fray in post-exilic Judea. Still, notwithstanding the underlying concern of this prevailing deuteronomistic theology of provisional grace - that God has taken, and hence obedience is required, and hence law (to the point, for instance, that even wisdom becomes theologised under the dictum of 'the fear of the Lord...') - the strength (sociological and theological) of the alternative is such that it is not suppressed. The patriarchal theology 
remains: God has given. Without that in-built theological ambiguity of the canon, something would have given...

\section{Postdating and Debating}

To review: in the initial section of this article (numbered 2 above), a summary was offered of my unfolding theory of the patriarchs; the subsequent section (numbered 3 above) analysed as a new development, broadly, how the patriarchal accounts formed a part of the puzzle of the canon as it developed within early post-exilic Judea. The relationship between the patriarchal figures and the accounts on them, as well as the relationship between the patriarchal tradents and the other concurrent socio-theological streams within post-exilic Judea, along with the way all of these found reflection in the canon-in-development at that time, were all highly complex. This complexity is detectable in the resultant canon - and that may well be why the canon was a successful instrument in bringing together and keeping some form of accord among the highly diverse yet intricately related groups within post-exilic Judea.

\section{BIBLIOGRAPHY}

Berndt, C \& Rathman, R 2003. A Bible history in the words of Holy Scripture. St Louis, MO: Concordia Publishing House.

Bos, JM 2013. Reconsidering the date and provenance of the book of Hosea: the case for Persian-period Yehud. London: Bloomsbury T\&T Clark.

Howard DM 2003. History as history: the search for meaning, in: Howard, DM \& Grisanti, MA (eds.) Giving the sense. Understanding and using Old Testament historical texts. Grand Rapids: Kregel Academic \& Professional, 25-53.

Assmann, A \& Assmann, J 1994. Das Gestern im Heute. Medien und soziales Gedächtnis, in: Merten, K, Schmidt, SJ \& Weischenberger, S (Hrsg.) Die Wirklichkeit der Medien. Eine Einführung in Kommunikationswissenschaften. Opladen: Westdeutscher Verlag, 114-140.

Davies, PR 2006. In search of 'ancient Israel'. Sheffield: Continuum.

Fantalkin, A \& Tal, O 2012a. The canonization of the Pentateuch: when and why? (Part I). Zeitschrift für die Alttestamentliche Wissenschaft 124/1 / DOI: 10.1515/zaw-20120001, 1-18.

Fantalkin, A \& Tal, O 2012b. The canonization of the Pentateuch: when and why? (Continued, Part II). Zeitschrift für die Alttestamentliche Wissenschaft 124/1/DOI: 10.1515/zaw-2012-00015, 201-212.

Gärtner, J 2012. Die Geschichtspsalmen. Eine Studie zu den Psalmen 78, 105, 106, 135 und 136 als hermeneutische Schlüsseltexte im Psalter (FAT 84). Tübingen: Mohr Siebeck.

Gershoni, I 1992. Imagining and reimagining the past: the use of history by Egyptian nationalist writers, 1919-1952. History and Memory 4/2, 5-37.

Le Roux, JH 2001. No theory, no science. (or: Abraham is only known through theory). Old Testament Essays 14/3, 444-457. 
Le Roux, J 1993. The nature of historical understanding (or: hermeneutics and history). Studia Historiae Ecclesiasticae XIX/1, 35-63.

Lombaard, C 2013a. Three old men? The patriarchs in the prophets (or: what do patriarchs look like, and where do we find them?). Journal for Semitics/Tydskrif vir Semitistiek 22/2, 276-288.

Lombaard, C 2013b. Jacob come lately? Hosea 12 and the problem of dating the patriarchs of ancient Israel. Paper read at the Sixteenth World Congress of Jewish Studies, Jerusalem, July 28-August 1 2013. Publication forthcoming.

Lombaard, C 2013c. Genesis 22, in: Roncace, M \& Weaver, J (eds.) Global Perspectives on the Bible. Upper Saddle River, NJ: Pearson, 34-36.

Lombaard, C 2011a. The Patriarchs and their Pentateuchal references: outlines of a new understanding. Tydskrif vir Semitistiek / Journal for Semitics, 20/2, 470-486.

Lombaard, C 2011b. Argumentum ex (fere) silentio. Reconsidering the (almost) silence on the patriarchs in the Psalter. Tydskrif vir Semitistiek / Journal for Semitics, 20/1, 139-151.

Lombaard, C 2011c. No empire, no Bible? Aspects of the relationship between biblical texts and current anti-empire views. Studia Historiae Ecclesiasticae XXXVII, 49-65.

Lombaard, C 2010. The exile of the patriarchs among the prophets: a new beginning, or first beginnings? Verbum et Ecclesia 31(1), ART. \#408. DOI: 10.4102/ ve.v31i1.408, 1-5.

Lombaard, C 2009. Isaac in the Old Testament. A new interpretation from Genesis 22, based on hermeneutical-methodological and exegetical investigations (DD dissertation). Pretoria: University of Pretoria.

Lombaard, C 2008. Isaac multiplex: Genesis 22 in a new historical representation. HTS Theological Studies 64/2, 907-919.

Lombaard, C 2005. What is Isaac doing in Amos 7?, in Otto, E \& Le Roux, J (eds.) A Critical Study of the Pentateuch. An Encounter Between Europe and Africa (Altes Testament und Moderne 20). Munich: LIT Verlag, 152-159.

Lombaard, C 1998. Some remarks on the patriarchs in the Psalms. Old Testament Essays $11 / 1,59-70$.

Lyotard, J-F 1979. La condition postmoderne: rapport sur le savoir. Paris: Minuit.

Miller, JM \& Hayes, JH 1986. A history of ancient Israel and Judah. Philadelphia: The Westminster Press.

Nissinen, M 1991. Prophetie, Redaktion und Fortschreibung im Hoseabuch. Studien zum Werdegang eines Prophetenbuches im Lichte von Hos 4 und 11. Kevelaer: Butzon \& Bercker.

Otto, E 2007. Scribal Scholarship in the formation of Torah and Prophets: a postexilic scribal debate between priestly scholarship and literary prophecy - the example of the book of Jeremiah and its relation to the Pentateuch, in: Knoppers, GN \& Levison, BM (eds.) The Pentateuch as Torah. New models for understanding its promulgation and acceptance. Winona Lake: Eisenbrauns, 171-184. 
Römer, T 2011. Older (pre-exilic) traditions in the Torah - the case of the patriarchal and the Moses traditions. Tel Aviv: The Ancient Israel Studies Program, Department of Archaeology and Ancient Near Eastern Cultures, Tel Aviv University, Scholarly Seminar Series.

Usue, EO 2005. Theological perspectives on the concept of 'Yahweh's people' in Ezra and Nehemiah during the early post-exilic period (539-350 BC) (PhD dissertation). Pretoria: University of Pretoria.

Voegelin, E 1956/57 Order and History (Vol. 1-3). Baton Rouge: Louisiana State University Press.

Von Rad, G 1962. Theologie des Alten Testaments (Band 1; 4. Auflage). München: Chr. Kaiser Verlag.

Wahl, HM 1997. Die Jakobserzählungen. Studien zu ihrer mündlichen Überlieferung, Verschriftung und Historizität. Berlin: Walter de Gruyter. 